\title{
SUBSTITUTE NAMES FOR THE EXTINCT GENERA \\ CYCLOPTERA MARTYNOVA (MECOPTERA) AND PARELCANA CARPENTER (ORTHOPTERA)*
}

\author{
By Frank M. Carptenter \\ Museum of Comparative Zoology \\ Harvard University, Cambridge, Mass. 02138
}

In 1958 Dr. Olga M. Martynova described a fossil mecopteron belonging to a new genus, Cycloptera, and representing a new family, Cyclopteridae. Since the name Cycloptera turns out to be preoccupied, a substitute name is needed. Dr. Martynova has asked me to propose a replacement name, and, following her suggestion for the name, I propose the following:

Cyclopterina, nomen novum, pro Cycloptera Martynova, 1958, p. 85, non Audinet-Serville, 1839, p. 439. The type species, Cycloptera autumnale Martynova, 1958, original designation, becomes Cyclopterina autumnalis (Martynova), new combination. The new generic name is derived from Cycloptera with the addition of the feminine suffix -ina and is considered feminine. The genus is known only from the Permian of the Kuznetz Basin, near the Tom River, Kemerovsk Region, USSR.

The family name, Cyclopteridae Martynova, 1938, p. 84, is herein replaced by Cyclopterinidae. Cyclopterina is the only genus known in the family at present.

In 1966 I described a Permian orthopteron, placing it in a new genus, Parelcana, of a new family, Parelcanidae. I have only recently realized that the name Parelcana is preoccupied and I take this opportunity to propose the following substitute name:

Anelcana, nomen novum pro Parelcana Carpenter, 1966, p. 84, non Handlirsch, 1906, p. 420. The type species, Parelcana dilatata Carpenter, 1966, original designation, becomes Anelcana dilatata (Carpenter), new combination. The new generic name is derived from Elcana with the prefix an ("not"). The genus is known only from the Permian of Kansas, U.S.A.

\footnotetext{
*Research supported by National Science Foundation grant DEB 8205398, F. M. Carpenter, Principal Investigator.
} 
The family name, Parelcanidae Carpenter, is herein replaced by Anelcanidae. The genus Petrelcana Carpenter (1966), from the same locality, is the only other genus in the family.

\section{REFERENCES}

Audenit-Serville, J. G.

1839. Histoire naturelle des insectes, Orthoptèrés. Paris Libraraire Encyclopédique de Roret, p. 1-776, pl. 1-14.

Carpenter, F. M.

1966. The Lower Permian insects of Kansas. Part 11. The orders Protorthoptera and Orthoptera. Psyche, 73: 48-88, Pl. 4-7, text-fig. 1-20.

HANDLIRSCH, ANTON

1906. Die fossilen Insekten und die Phylogenie der rezenten Formen. P. 1-640, pl. 1-26, Engelmann (Leipzig).

Martynova, O. M.

1958. Novye nassekomye ix permskikh i mezozojskikh ot lozxgenij SSSR. Materialy k Osnovam Paleontologii, 2: 69-94, text-fig. 1-23. 



Submit your manuscripts at

http://www.hindawi.com
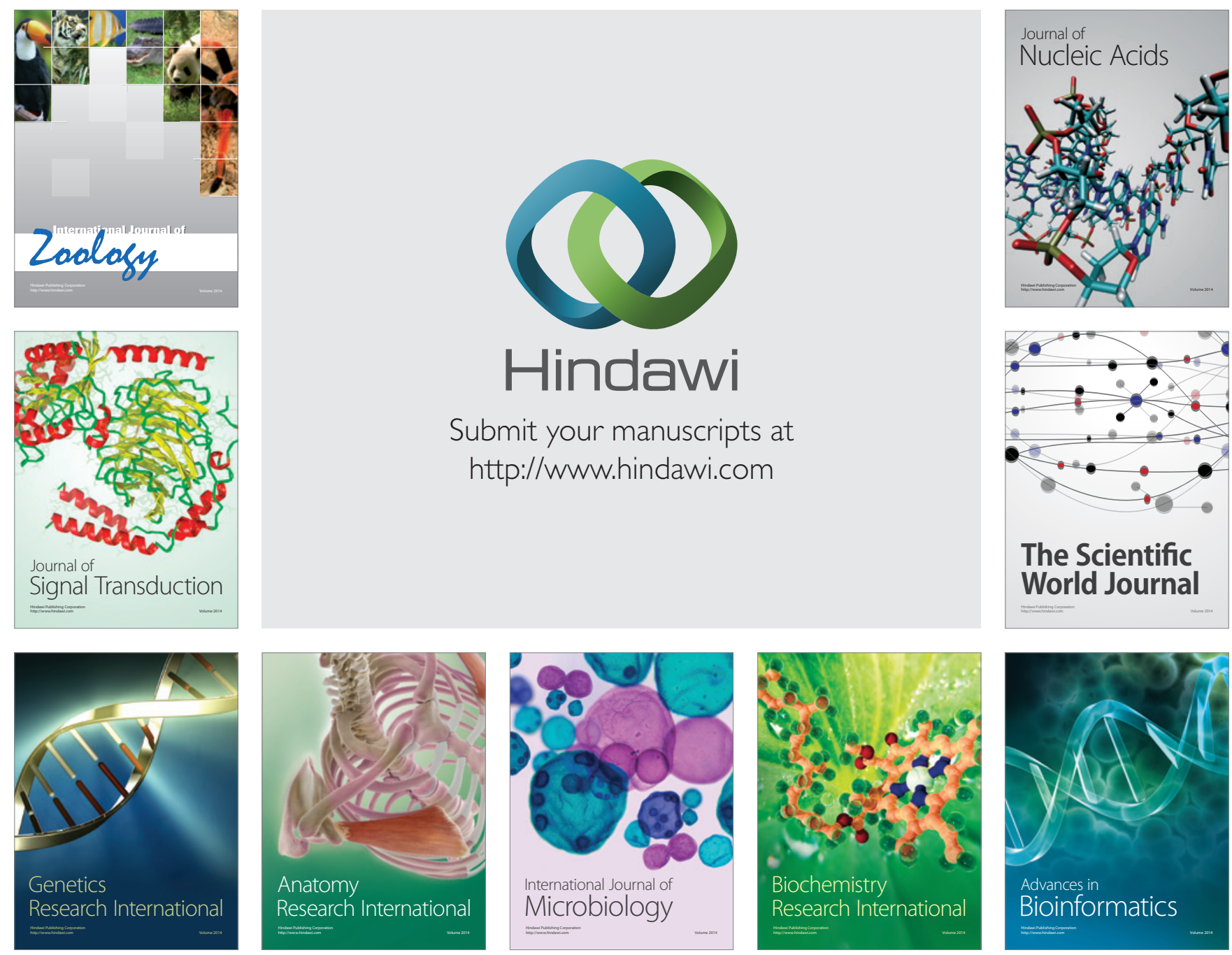

The Scientific World Journal
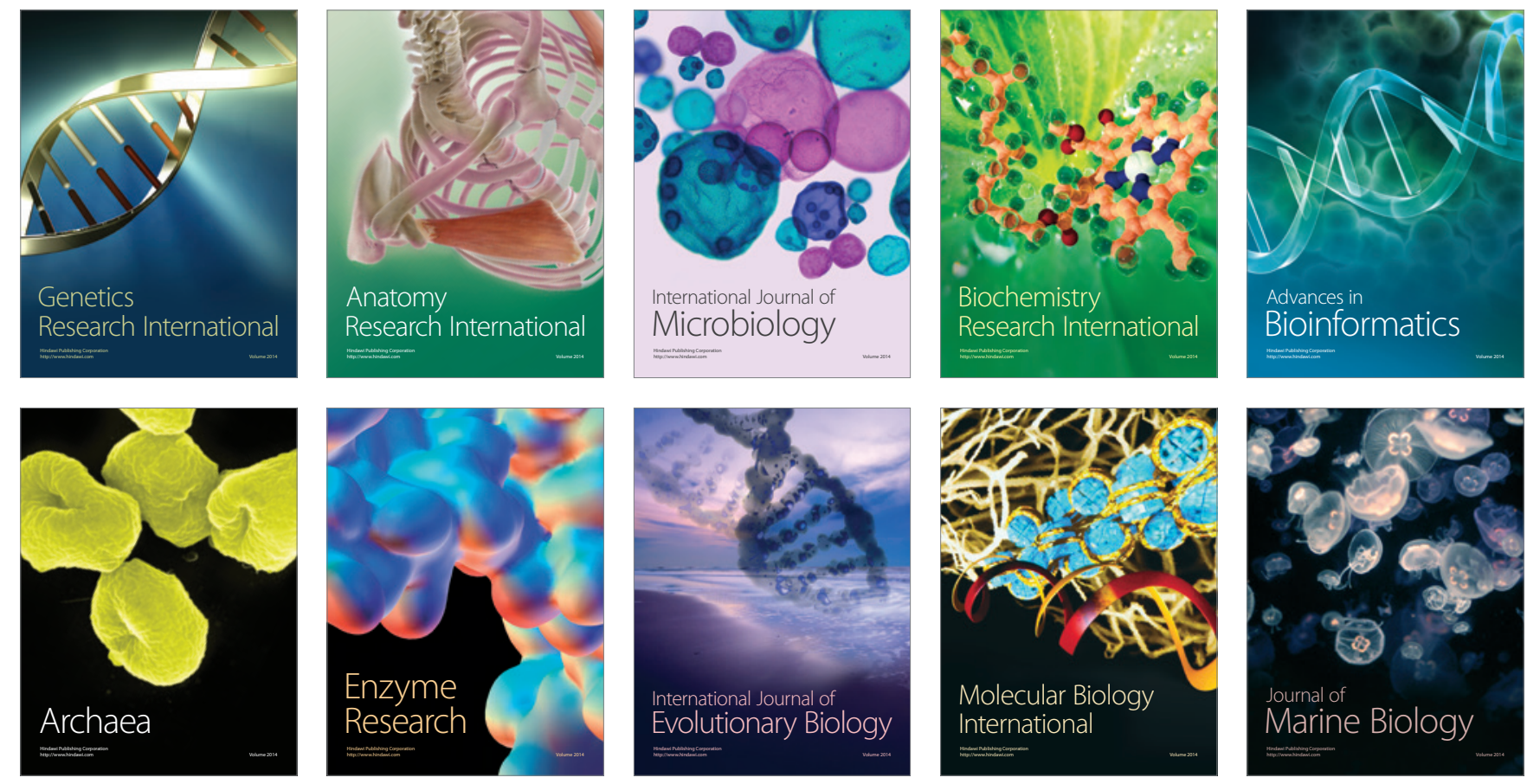